\title{
Incorporation of Okara into Gluten-Free Cookies with High Quality and Nutritional Value
}

\author{
María V. Ostermann-Porcel, ${ }^{1}$ Natalia Quiroga-Panelo, ${ }^{2}$ \\ Ana N. Rinaldoni, ${ }^{1}$ and Mercedes E. Campderrós ${ }^{1}$ \\ ${ }^{1}$ Instituto de Investigaciones en Tecnología Química (INTEQUI-CONICET), Facultad de Química, Bioquímica y Farmacia, \\ Universidad Nacional de San Luis, Ejército de los Andes, 950-5700 San Luis, Argentina \\ ${ }^{2}$ Facultad de Ciencias de la Salud, Universidad Nacional de San Luis, Ejército de los Andes, 950-5700 San Luis, Argentina
}

Correspondence should be addressed to Mercedes E. Campderrós; mcamp@unsl.edu.ar

Received 7 July 2016; Revised 13 September 2016; Accepted 18 September 2016; Published 11 January 2017

Academic Editor: Giuseppe Zeppa

Copyright (C) 2017 María V. Ostermann-Porcel et al. This is an open access article distributed under the Creative Commons Attribution License, which permits unrestricted use, distribution, and reproduction in any medium, provided the original work is properly cited.

\begin{abstract}
Soy products are a source of protein relatively inexpensive and recognized for their high nutritional value and functional properties. Okara is a byproduct from soy milk production. Gluten-free cookies have been developed using okara and commercial manioc flour. Four formulations were developed with different proportions of okara: 50\%; 30\%; 15\%; and 0\%. Physicochemical, physical properties, sensory analysis, and nutritional studies were performed. The use of inulin as partial replacement of sugar was evaluated. The incorporation of okara increased protein and fiber content. Furthermore, the hardness of cookies increased while the index of whiteness decreased. From the sensory evaluation, it could be concluded that the cookies presented a great acceptability. The cookies developed in this study have functional characteristics, providing added value to a waste product; furthermore the products were suitable for celiacs with acceptable quality and improved nutrition value.
\end{abstract}

\section{Introduction}

The celiac disease is a genetically predisposed autoimmune disorder that results in damage to the lining of the small intestine when foods with gluten are eaten [1]. The damage to the intestine makes it hard for the body to absorb nutrients, especially fat, calcium, iron, and folate. Gluten is a protein found in some grains which possesses a structureforming ability that affects the elastic properties of dough and contributes to the overall appearance and crumb structure of many baked products [2]. Nowadays, there is a high need for the development of food products that increase the availability of gluten-free food in order to attend an increasing demand. This constitutes an actual technological challenge with a wide possibility for investigation $[3,4]$.

Flour habitually used to elaborate gluten-free products from bread-making products is based on rice, maize, and manioc. As some of these preparations have either low protein or low fiber content, biological active components such as minerals, vitamins, oily acids, and fiber are added. A source of suitable nutrients for celiac sufferers is found in soybean and its derivatives [5].

In Argentina soybean covers a wide cultivated surface, with a low industrialization not only of the grain but also of its derivative products [6]. Soy proteins provide all the essential amino acids needed to fulfil human nutritional requirement for growth and maintenance. Vitamin and mineral fortification of soy protein products are both feasible and nutritionally sound. The phytoestrogens of soy proteins may reduce cancer risk or interfere with the cancer process. Isoflavones can also help to prevent osteoporosis and cancers, such as colon, breast, and prostate, and offers women relief for menopausal discomfort [7]. Moreover, cardiovascular risk disease may be diminished since protein soy reduces blood cholesterol levels, low-density lipoprotein (LDL) cholesterol fraction, and triglycerides in humans [8].

A byproduct obtained during the processing of soybeans for the production of soy milk is okara, also called soybean 
paste. It is yellowish white with a neutral, smooth flavor. It consists of an insoluble fraction obtained from the hydrothermal treatment of the crushed soybean. This residue is generally discarded causing a significant environmental problem because it is susceptible to putrefaction due to its high moisture content ( $\cong 80 \%)$. This byproduct still contains many beneficial components, which has attracted the increasing current interest in functional foods. Furthermore, the development of techniques for value-addition generates not only great nutritional interest but also environmental significance. Besides its soft taste, colorless appearance, and easily digestible carbohydrates, okara is suitable for gluten-free product formulations [9].

Cereal-based cookies, crackers, and breakfast cereals are products that represent an important source of energy in human nutrition. Cookies are widely accepted and consumed in many countries because they have a broad range of choices to be enjoyed as a snack with longer shelf life and low cost [10] and represent baked products containing three major ingredients: flour, sugar, and fat, which are mixed together with other minor ingredients to form cookie dough [11].

The main attributes that affect cookie quality are texture, flavor, and appearance [2]. Another important aspect in designing cookies with improved nutritional status is the maintenance of product's sensory characteristics because the consumers' acceptability remains the key factor which determines the successful application of a newly developed product [12]. During baking, the undissolved sugar progressively dissolves and hence contributes to cookie spread. Other parameters that are influenced by the recipe's sugar include cookie hardness, crispness, color, and volume. Fat contributes to cookie spread and to general product appearance; it enhances aeration for leavening and volume and makes the cookies more easily breakable [13].

The substitution of sugar for inulin was carried out with the purpose of developing a functional food formulation which combined high quality proteins and health benefits, but it does not reduce the sensory quality. Inulins are a group of naturally occurring polysaccharides produced by many types of plants. This compound increases calcium absorption, while promoting the growth of intestinal bacteria [14]. Furthermore, it is a soluble fiber, categorized as a prebiotic $[15,16]$. Inulin has a minimal impact on blood sugar, and, unlike fructose, it is not insulinemic and it does not raise triglycerides, which is generally considered suitable for diabetics and potentially helpful in managing blood sugarrelated illnesses [17]. Inulin is widely used in the processed food as a fat or sugar replacer or to impart desirable characteristics and it gives only $25-35 \%$ energy as compared to digestible carbohydrates [18].

Although okara flour has been evaluated as a food ingredient in numerous studies, detailed information on the improvement of the nutritional profile or enriched products is rather scanty.

The main goal of this study was to determine the effect of partial replacement of manioc flour with okara flour in different formulations of gluten-free cookies with acceptable taste and appearance. The impact of sugar reduction on technological factors of finished sweet cookies was assessed. A detailed study on the chemical composition and on the textural and sensory attributes of cookies was also conducted. Additionally, their nutritional quality was evaluated and compared.

\section{Materials and Methods}

2.1. Raw Material. Okara flour was prepared in the laboratory. Soybean was soaked in water for $8-10 \mathrm{~h}$ at ambient temperature. It was ground in blender (SIAM LIC07) incorporating water at $100 \pm 1^{\circ} \mathrm{C}$ to enhance the grinding. A thermal treatment was applied during 20 minutes at a temperature superior of $90 \pm 1^{\circ} \mathrm{C}$ in order to reduce the activity of the trypsin inhibitor and deactivate the lipoxygenase enzyme which provokes the unpleasant taste. The soybean liquid is separated and the resulting suspension constitutes the wet okara that is later dried off and packed.

The manioc starch (1.2\% protein, $1.6 \%$ crude fiber, $0.4 \%$ fat, $0.8 \%$ ash, and $13.01 \%$ carbohydrate) [19] was purchased in local market, as well as the other ingredients. The inulin was provided by Orafti Chile S. A. The commercial inulin employed was mainly constituted of linear chains of fructose, with a glucose terminal unit, and had a molecular weight of $2400 \mathrm{~g} / \mathrm{mol}$.

2.2. Cookie Preparation. For the production of cookies, okara flour was prepared to be mixed with manioc flour in different concentrations. The cookies were prepared using the following ingredients: manioc flour $(\mathrm{M})$, okara $(\mathrm{O})$, margarine, sugar, eggs, vanilla essence, baking powder, and xantic guar + guar gum. Four formulations were developed: one with manioc flour (without okara) as control (C) and three others with different proportions of okara: 50\% (50-O); 30\% (30$\mathrm{O})$; and $15 \%(15-\mathrm{O})$. Cookies were baked at $180^{\circ} \mathrm{C}$ for $10 \mathrm{~min}$. Once baked, the cookies were cooled up to room temperature. Finally, they were packed in polypropylene bags and stored at $25 \pm 1^{\circ} \mathrm{C}$ during 60 days.

In addition, the effect of partial replacement (30\%) of sugar with inulin (I) was investigated for cookies with $30 \%$ of okara (30-O). The sample was labeled 30-OI.

2.3. Proximate Composition. Standard methods of analysis [20] were used to determine protein content by establishing total nitrogen by the Kjeldahl method using a Digestion Block and a semiautomatic Distiller (Selecta, Spain) with a conversion factor of 6.25 (AOAC 991.22); fat content by Soxhlet extraction (AOAC 945.39); moisture content by gravimetric method (AOAC 925.10); dry matter by weight difference (AOAC 925.23); ash by incineration (AOAC 945.46); and carbohydrate by weight difference [21].

All determinations were performed in triplicate.

2.4. Physical Characteristics. Different parameters that can be easily assessed at the end of the baking process include physical dimensions such as cookie length, width, and height, along with measures of color. These values are essential for maintaining product quality [22].

2.4.1. Cookie Dimensions. Diameter and thickness were measured with a vernier caliper at three different places in each 
cookie and the average was calculated for each. The average of 6 cookies was recorded for each batch. In order to determine the flour quality, the spread ratio (SR) was calculated using the following equation [23], assigning the best quality to those that obtained a higher absolute value [24]:

$$
\mathrm{SR}=\frac{\text { Diameter of cookies }}{\text { Height of cookies }} \text {. }
$$

2.4.2. Specific Volume of the Cookies. The specific volume (SV) of the cookies was determined by the seed displacement method, $2 \mathrm{hr}$ after baking by [25]. It was obtained by the following equation:

$$
\mathrm{SV}=\frac{\text { Weight of each sample }}{\text { Volume displacement by each sample }} .
$$

2.4.3. Textural Profile Analysis. The textural characteristics of the cookies were determined through a three-point bending test performed on a texture analyzer (TMS-TOUCH, Food Technology Corporation, USA) as described [26]. In this test, two beams at a known distance support the product. A third beam is brought down through the product at a point equidistant from both support beams. With a blade $(70 \mathrm{~mm}$ wide and $3 \mathrm{~mm}$ thick), a downward movement of the top beam is exerted until the product breaks. A texture analyzer, with the $50 \mathrm{~N}$ load cell, was used in the measure force in compression mode. The cookies were analyzed at a test speed of $70 \mathrm{~mm} \mathrm{~min}^{-1}$. The maximum force required to break a single cookie was recorded and the average value of 10 cookies for each batch was reported.

2.4.4. Analysis of Surface Color. The color values of the cookies were measured in three different zones of the crust using a digital spectrophotometer Mini Scan EZ (HunterLab, USA) which was provided with the software. A chronometer was calibrated with the standard black and white color. The results reported are averages of three measurements in each sample using CIELAB $L^{*}, a^{*}$, and $b^{*}$ values. $L^{*}$ value is the lightness variable from 100 for perfect white to zero for black, while $a^{*}$ and $b^{*}$ values are the chromaticity values, +redness/-greenness and +yellowness/-blueness, respectively [27]. Whiteness Index (WI) for each sample was calculated according to the following equation [28]:

$$
\mathrm{WI}=100-\left[\left(100-L^{*}\right)^{2}+a^{* 2}+b^{* 2}\right]^{1 / 2} .
$$

2.4.5. Microstructure Study. The microstructure of cookies was evaluated across analysis of image by scanning electron microscopy (SEM, LEO1450VP, Zeiss, Germany). The samples were mounted on double-sided adhesive carbon on aluminum sample holders. The micrographics were determined under VP mode (variable pressure), using 300x magnification. The low vacuum mode of SEM is a special type, where the chamber can be maintained at low vacuum at $70 \mathrm{~Pa}$, while the column remains under vacuum. In this way, it is possible to observe biologically sensitive samples without dehydrating or metalizing with gold [29].
2.5. Caloric Value and Nutrition Information. SARA software (Sistema de Análisis y Registro de Alimentos) was used. This software provides a table of food chemical composition which was developed by the National Survey of Nutrition and Health (ENNyS), and it was based on the predominant national consumption.

The calories of cookies were determined considering all the ingredients used in the formulation (expressed in grams) and their corresponding quantities. Finally, the conversion of grams to calories was performed. For nutritional labeling, the US Food and Drug Administration (FDA) suggests caloric content to be calculated by a procedure using 4,9 , and 4 calories per gram of protein, fat, and carbohydrate, respectively. The total dietary fiber content was subtracted from the total carbohydrate content before calories was calculated [30].

2.6. Sensory Evaluation. The first sensory analyses of glutenfree cookies were carried out $2 \mathrm{hr}$ after baking in a uniformly illuminated room by 70 untrained 18-55-year-old panel members. The samples were coded with three-digit numbers and were presented in a randomized order. The attributes were estimated on a seven-point scale (from 1 = I like very much to $7=$ I dislike very much) with a neutral point at 4 (neither like nor dislike). The sensory attributes evaluated were color, flavor, taste, and manual texture. Apples were provided between samples to cleanse the palate. Then, a statistical analysis was performed using the Friedman test, which determines whether the sums of the total orders for each sample differ significantly [31].

The second group of sensory analyses consisted of a double comparison test (preference) between the samples 30$\mathrm{O}$ and 30-OI, which were coded with three-digit numbers and were presented in a randomized order. The test was conducted by another 70 untrained panel members, different from the previous ones.

2.7. Statistical Analysis. Results are expressed as means with standard deviations of analysis performed in triplicate. Oneway analysis of variance and Tukey's test were used to establish the significance of differences among mean values at $p \leq 0.05$. The statistical analyses were performed using GraphPad InStat Software Inc.

\section{Results and Discussion}

3.1. Proximate Composition. The okara quality was evaluated before being incorporated into the cookies. Although okara is currently considered an object of study and a novel component in the food industry, it has not been incorporated into national or international tables of food chemical composition yet. For this reason, the proximate composition of okara flour was determined in the laboratory. The protein content was $34.61 \pm 1.49 \%$; fiber $20.37 \pm 1.20 \%$; fat $19.10 \pm 4.67 \%$; ash $3.44 \pm 0.41 \%$; moisture $1.38 \pm 0.14 \%$; and total carbohydrates $21.11 \pm 1.58 \%$. Similar results were reported [32, 33]; however, it is a common knowledge that the chemical composition of okara will depend on the procedure followed to obtain it. 
TABle 1: Proximate composition of cookies.

\begin{tabular}{lcccccc}
\hline Sample & Moisture (\%) & Ash (\%) & Protein (\%) & Fat (\%) & Fiber (\%) & Total carbohydrates (\%) \\
\hline Control & $5.79 \pm 0.71^{\mathrm{a}}$ & $0.25 \pm 0.04^{\mathrm{a}}$ & $3.26 \pm 0.96^{\mathrm{a}}$ & $15.40 \pm 1.00^{\mathrm{a}}$ & - & 75.29 \\
$15-\mathrm{O}$ & $5.41 \pm 2.30^{\mathrm{a}}$ & $0.41 \pm 0.08^{\mathrm{a}}$ & $5.40 \pm 0.12^{\mathrm{b}}$ & $15.91 \pm 1.16^{\mathrm{a}}$ & $1.32 \pm 0.18^{\mathrm{a}}$ & 71.54 \\
$30-\mathrm{O}$ & $4.75 \pm 0.28^{\mathrm{a}}$ & $0.64 \pm 0.03^{\mathrm{b}}$ & $8.80 \pm 0.24^{\mathrm{c}}$ & $16.80 \pm 1.09^{\mathrm{a}}$ & $3.16 \pm 1.05^{\mathrm{b}}$ & 65.85 \\
$50-\mathrm{O}$ & $5.09 \pm 0.18^{\mathrm{a}}$ & $0.79 \pm 0.07^{\mathrm{b}}$ & $12.84 \pm 0.97^{\mathrm{d}}$ & $22.10 \pm 0.38^{\mathrm{b}}$ & $3.93 \pm 0.4^{\mathrm{b}}$ & 55.24 \\
$30-$ OI & $6.83 \pm 0.56^{\mathrm{b}}$ & $0.66 \pm 0.04^{\mathrm{b}}$ & $8.76 \pm 0.36^{\mathrm{c}}$ & $17.66 \pm 0.16^{\mathrm{a}}$ & $3.37 \pm 1.47^{\mathrm{b}}$ & 62.71 \\
\hline
\end{tabular}

All values are means with standard deviation $(n=3)$. Different letters within the same column differ significantly from each other $(p<0.05)$.

TABLE 2: Physical properties of cookies.

\begin{tabular}{|c|c|c|c|c|c|c|c|}
\hline \multirow{2}{*}{ Sample } & \multirow{2}{*}{ Spread ratio } & \multirow{2}{*}{ Specific volume $(\mathrm{g} / \mathrm{mL})$} & \multirow{2}{*}{ Hardness (N) } & \multicolumn{4}{|c|}{ Color } \\
\hline & & & & $L^{*}$ & $a^{*}$ & $b^{*}$ & WI \\
\hline Control & $0.27 \pm 0.01^{\mathrm{a}}$ & $0.73 \pm 0.35^{\mathrm{a}}$ & $22.08 \pm 3.5^{\mathrm{a}}$ & $76.57 \pm 0.84^{\mathrm{a}}$ & $2.98 \pm 0.12^{\mathrm{a}, \mathrm{b}}$ & $16.21 \pm 0.54^{\mathrm{a}}$ & 69.35 \\
\hline $15-\mathrm{O}$ & $0.20 \pm 0.01^{\mathrm{b}}$ & $0.57 \pm 0.06^{\mathrm{a}}$ & $25.54 \pm 2.9^{\mathrm{a}, \mathrm{c}}$ & $77.91 \pm 0.38^{\mathrm{a}}$ & $4.87 \pm 0.37^{\mathrm{a}}$ & $20.68 \pm 1.05^{\mathrm{b}}$ & 71.35 \\
\hline $30-\mathrm{O}$ & $0.19 \pm 0.01^{b}$ & $0.59 \pm 0.19^{\mathrm{a}}$ & $31.01 \pm 6.0^{\mathrm{c}, \mathrm{b}}$ & $74.63 \pm 1.82^{\mathrm{b}}$ & $5.75 \pm 1.5^{c, d}$ & $20.635 \pm 1.4^{\mathrm{b}}$ & 66.79 \\
\hline $50-\mathrm{O}$ & $0.17 \pm 0.01^{\mathrm{a}}$ & $0.49 \pm 0.03^{\mathrm{a}}$ & $31.76 \pm 6.7^{\mathrm{b}}$ & $68.98 \pm 0.29^{b}$ & $8.03 \pm 0.86^{\mathrm{d}}$ & $24.61 \pm 0.05^{\mathrm{c}}$ & 59.59 \\
\hline 30-OI & $0.20 \pm 0.23^{\mathrm{b}}$ & $0.56 \pm 0.06^{\mathrm{a}}$ & $27.41 \pm 2.7^{\mathrm{a}, \mathrm{c}}$ & $71.94 \pm 3.37^{\mathrm{b}}$ & $7.60 \pm 2.60^{\mathrm{d}}$ & $25.44 \pm 3.7^{\mathrm{c}}$ & 61.37 \\
\hline
\end{tabular}

All values are means with standard deviation $(n=3)$. Different letters within the same column differ significantly from each other $(p<0.05)$.

Data on the chemical composition of cookies are presented in Table 1. As expected, the protein and fiber content increased with the level of substitution of okara flour. The replacement with okara flour caused a decrease in carbohydrates and an increase in fat and ash content. The moisture content was not significantly affected by the partial replacement of manioc flour with okara. Cookies presented a moisture content established by CAA [21]. The use of inulin affected the moisture content; this is due to its water-holding capacity which increase the moisture content of the final product.

3.2. Physical Characteristics. Table 2 displays the physical properties of cookies prepared with different okara contents.

The spread factor is an important characteristic for determining the quality of cookies. Cookies with higher spread ratios are considered the most desirable. An increase in okara content significantly decreased the spread ratio of the cookies, which is directly related to the height of the cookies, whereas the diameter was generally not affected. As reported [34, 35] a decrease in spread with increased protein in the cookies was noticed. Consequently, the higher protein content for the okara flour used in this study may have contributed to the reduced spread.

The higher the replacement of okara, the lower the specific volume. This is possibly due to the fibers present in the okara flour, which might interfere in the structure of the matrix, diminishing the gas retention capacity in the dough.

Another physical parameter evaluated was texture, which is an important factor in cookie quality evaluation [11]. Hardness is measured by peak force to break the cookie. The fracture force of cookies was significantly affected by the increase in okara content. Table 2 shows that the force required for breaking cookies increased as the content of okara flour increased, as a result of the presence of fibers and proteins which compact the structure of the dough. In addition, a reduction in hardening of cookies with inulin was observed.

The surface color of a baked product is, together with texture and taste, a very important element for the initial acceptability of baked goods by consumers [36]. The increase in color values may be attributed to interaction of protein and sugar at baking temperatures resulting in a higher degree of Maillard reaction [37]. The results showed that when the color surface of cookies was evaluated across the space CIELAB, darkening was verified due to the incorporation of okara. However, when comparing $L^{*}$ values, statistically significant differences were found between samples: control and 15-O in comparison with 30-O and 50-O. When comparing $a^{*}$ and $b^{*}$, an increase in the values with the replacement of okara was observed $(p<0.05)$. This result indicates a browning of the crust with the incorporation of okara, demonstrating a marked reddish-dun color and an increased yellowness. According to [38] protein content was negatively correlated with lightness of a cookie, indicating that the Maillard reaction played a major role in color formation. The whiteness index (WI) combines lightness and yellow-blue into a single term.

The WI of the control and 15-O samples was higher than the remaining samples. As the okara content increased, a reduction of WI values was observed. It has also been reported that protein content has a negative correlation with whiteness [36]. Formulations with inulin resulted in a darker crust color, compared with $30-\mathrm{O}$ samples.

3.2.1. Microstructure Study. Figure 1 shows the scanning electron microscopy (SEM) of the cookie matrix. With the okara content in the formulation, a denser matrix was observed due to the increase in fiber and protein content that compacted the structure in relation to the control sample. Nevertheless, the images showed no noticeable difference under scanning electron microscopy. 


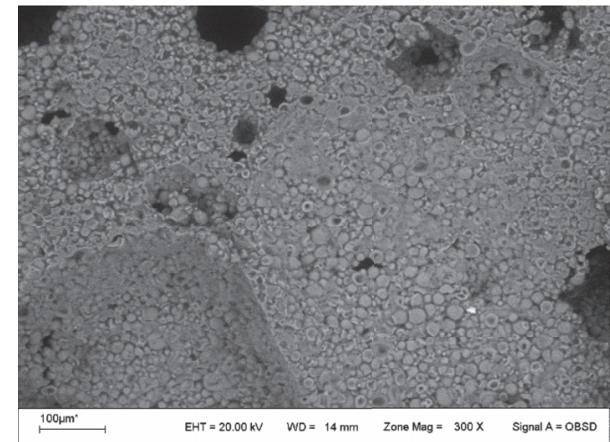

(a)

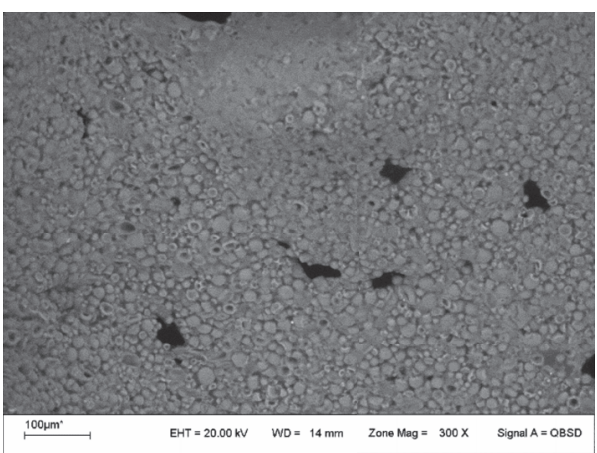

(c)

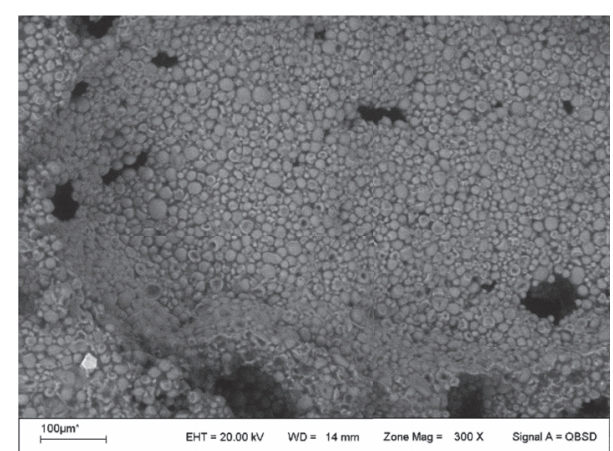

(b)

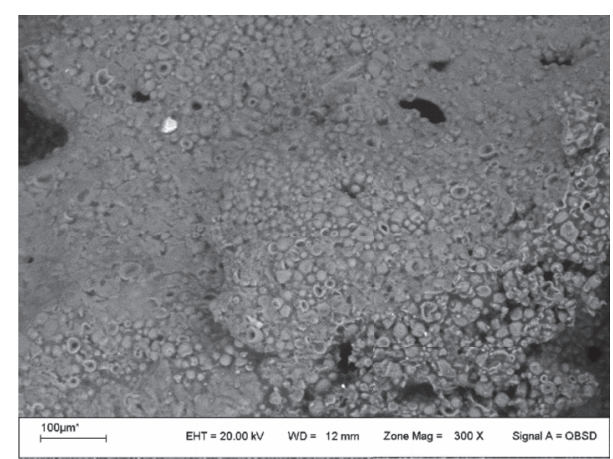

(d)

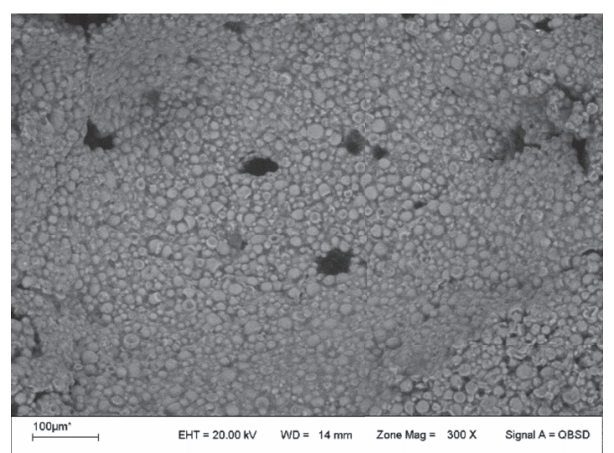

(e)

Figure 1: Scanning electron microscopy (SEM) of gluten-free cookie matrix. Magnification: 300x. (a) Control; (b) 15-O; (c) 30-O; (d) 50-O; and (e) 30-OI.

3.3. Caloric Value and Nutritional Information. Table 3 shows the results obtained for caloric value in each sample. With a greatest incorporation of okara in the formulation, a decrease in total carbohydrates and an increase in fiber, protein, and fat content were observed.

Dietary fiber plays an important role in many physiological processes and in the prevention of diseases of different origin. Therefore, daily intake of food rich in dietary fiber is important to reduce or regulate plasma cholesterol and triacylglycerol levels and to promote health [8]. Okara proteins are of high quality, since all the essential amino acids are present, having the capacity to reduce triglycerides and cholesterol. The bounding amino acid is the methionine, whereas the content of lysine exceeds the established requirements, which would make its use feasible in the
TABLE 3: Total caloric values.

\begin{tabular}{lccccc}
\hline & Control & $15-\mathrm{O}$ & $30-\mathrm{O}$ & $50-\mathrm{O}$ & $30-\mathrm{OI}$ \\
\hline Total carbohydrates $(\mathrm{g})$ & 460.9 & 425.03 & 389.3 & 341.6 & 345.1 \\
Fiber $(\mathrm{g})$ & 0 & 11 & 22 & 36.75 & 23 \\
Protein & 18 & 36.3 & 54.6 & 126.3 & 54.6 \\
Fat $(\mathrm{g})$ & & & & & \\
$\quad$ Saturated & 92.6 & 92.6 & 92.6 & 92.6 & 92.6 \\
$\quad$ Unsaturated & - & 8.3 & 16.6 & 27.6 & 16.6 \\
Kcal (total) & 2749 & 2753.7 & 2758.4 & 2953.4 & 2580 \\
\hline Kcal $(100 \mathrm{~g})$ & 386.25 & 386.9 & 387.6 & 386.9 & 362.5 \\
\hline
\end{tabular}

supplementation of gluten-free flour. With respect to soy fats, they are unsaturated, known as cardiohealthy fats, and they 


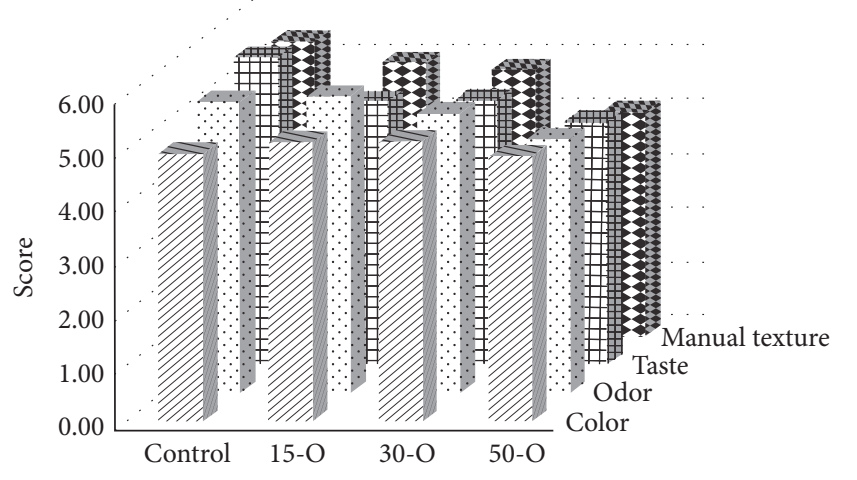

FIGURE 2: Sensory assessment.

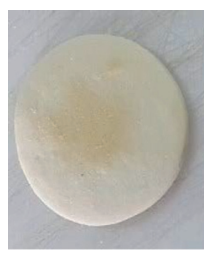

(a)

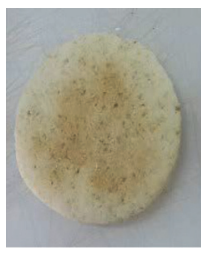

(b)

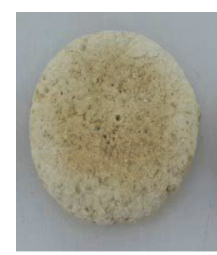

(c)

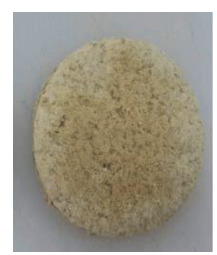

(d)

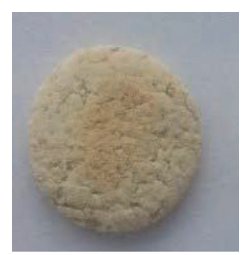

(e)

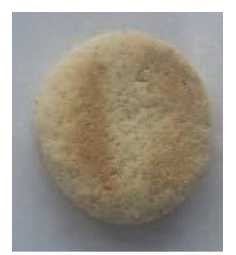

(f)

FIGURE 3: Photographs of cookies with different okara levels. (a) Control; (b) 15-O; (c) 30-O; (d) 50-O; and (e) 30-OI.

have isoflavones or phytoestrogens [32]. These are vegetable substances that have hormonal functions in the organism and protect it against chronicle diseases [39]. Okara contains an essential type of Omega 3 fatty acid [32].

Cookies with inulin presented a lower value of kilocalories by $100 \mathrm{~g}$. The low caloric value of inulin is due to its nondigestibility into its constituent monosaccharide moieties. Further scientific observations have also proved less energy account of inulin, where the energy value ranging from 1 and $1.5 \mathrm{kcal} / \mathrm{g}$ is being used for food tagging [18].

With the increase of okara, a minor value of kilocalories by $100 \mathrm{~g}$ was obtained. Nevertheless, the difference was not significant.

3.4. Sensory Evaluation. Figure 2 represents the sensory properties (color, flavor, taste, and manual texture) of glutenfree cookies with different concentrations of okara. According to the total sensory scores, the samples exhibited great acceptable sensory characteristics (Figure 2). Control sample was observed to have higher level of acceptance. Nevertheless, the panellist preferred the gluten-free cookies with $30-\mathrm{O}$ among samples containing okara. The addition of higher content of okara (50\%) in the formulation had negative effects on the color, aroma, taste, and overall acceptability as compared to the regarding samples. Hence, 30-O formulation was selected to be evaluated with a partial replacement of sugar content with inulin, which is colorless and odorless, and has a pleasant, slightly sweet taste. Results showed that, in consumer preference tests, both samples presented a good acceptability. However, the order of preference by the panellists was 30-O $>30$-OI. The photograph of cookies containing different levels of okara is shown in Figure 3.

\section{Conclusion}

Even though okara is a byproduct, it contains many beneficial components from soybean. In this study, it was determined that okara can be used to obtain gluten-free cookies without any additives and with acceptable physical and sensory qualities similar to those made with manioc flour.

According to the total sensory scores, the samples exhibited great acceptable sensory characteristics among consumer panel members. The samples containing lower okara (15\% or $30 \%$ ) provided more desirable sensory attributes than the sample containing higher content (50\%).

The physicochemical analyses revealed that the principal nutritional advantage of gluten-free cookies elaborated with okara is its high fiber and protein content. The partial replacement of sugar evaluated did not affect the composition of cookies.

According to the physical properties, the incorporation of okara into the formula reduced the size of the product, giving rise to harder and darker cookies. It was observed that an increase in okara content decreased the spread ratio of the cookies. In addition, an increase in the hardness of cookies was detected, since the structural network of the dough is strengthened due to the fiber content. The WI decreased with the incorporation of okara into the formulation, which could be attributed to the reactions of nonenzymatic browning generated in the process. The study of optical microscopy revealed that the samples did not present structural differences.

The employment of inulin did not affect the assessed characteristics compared to those cookies elaborated with sugar. The decrease in caloric value by $100 \mathrm{~g}$ was not different 
between samples. However, the use of inulin makes these cookies nutritionally interesting, since it is a functional food additive due to its prebiotic properties. Furthermore, it has been demonstrated that soy foods in conjunction with a prebiotic resulted in significant improvements in the lipid profile [40].

The incorporation of okara increases the nutritional value of the cookies. They are a source of vegetable proteins with high biological value, allowing their identification as a functional food.

\section{Additional Points}

Practical Application. A byproduct obtained during the processing of soybeans for the production of soy milk is okara. This material is yellowish white with neutral flavor and smooth, consisting of insoluble fraction obtained from the hydrothermal treatment of crushed soybean. Okara contains mainly insoluble fiber and complex carbohydrates that provides a low glycemic index; its proteins are of high quality, having the ability to reduce triglycerides and cholesterol. Also, it contains polyunsaturated fatty acids and isoflavones. An important characteristic is that okara flour does not contain gluten, so it is suitable for celiacs. The purpose of this study was to determine the effect of partial replacement of manioc flour with okara in different formulations of gluten-free cookies with acceptable taste and appearance. In addition, the use of inulin as partial replacement of sugar was assessed. Based on the results, cookies with high nutritional value can be obtained, allowing their identification as a functional food.

\section{Competing Interests}

There is no conflict of interests regarding the publication of this paper.

\section{Acknowledgments}

Financial support was provided by the SCyT, UNSL (Project 2-3114), and PICT 2012-0155 (ANPCyT). Also the authors would like to acknowledge fellowships of Eng. Ostermann Porcel (ANPCyT).

\section{References}

[1] H. Mirhosseini, F. A. Rashid, B. T. Amid, K. W. Cheong, M. Kazemi, and M. Zulkurnain, "Effect of partial replacement of corn flour with durian seed flour and pumpkin flour on cooking yield, texture properties, and sensory attributes of gluten free pasta," LWT_Food Science and Technology, vol. 63, pp. 184-190, 2015.

[2] A. Torbica, M. Hadnadev, and T. D. Hadnadev, "Rice and buckwheat flour characterisation and its relation to cookie quality," Food Research International, vol. 48, no. 1, pp. 277-283, 2012.

[3] A. N. Rinaldoni, D. R. Palatnik, N. Zaritzky, and M. E. Campderrós, "Soft cheese-like product development enriched with soy protein concentrates," LWT-Food Science and Technology, vol. 55, no. 1, pp. 139-147, 2014.

[4] F. Sansone, P. Picerno, T. Mencherini et al., "Enhanced technological and permeation properties of a microencapsulated soy isoflavones extract," Journal of Food Engineering, vol. 115, no. 3, pp. 298-305, 2013.

[5] M. Foschia, S. Horstmann, E. K. Arendt, and E. Zannini, "Nutritional therapy-facing the gap between coeliac disease and gluten-free food," International Journal of Food Microbiology, 2016.

[6] J. Strada and I. A. Vila, "La producción de soja en Argentina: causas e impactos de su expansión," La Revista del CCC, no. 23, 2015, http://www.centrocultural.coop/revista/articulo/550/.

[7] H. D. Genta, M. L. Genta, N. V. Álvarez, and M. S. Santana, "Production and acceptance of a soy candy," Journal of Food Engineering, vol. 53, no. 2, pp. 199-202, 2002.

[8] A. Redondo-Cuenca, M. J. Villanueva-Suárez, and I. MateosAparicio, "Soybean seeds and its by-product okara as sources of dietary fibre. Measurement by AOAC and English methods," Food Chemistry, vol. 108, no. 3, pp. 1099-1105, 2008.

[9] A. Aguado, Development of okara powder as a gluten free alternative to all purpose flour for value added use in baked goods [Thesis], Faculty of the Graduate School of the University of Maryland, College Park, Md, USA, 2010, http://hdl.handle.net/ 1903/11281.

[10] A. R. Abdel-Moemin, "Healthy cookies from cooked fish bones," Food Bioscience, vol. 12, pp. 114-121, 2015.

[11] A. A. Wani, D. S. Sogi, P. Singh, P. Sharma, and A. Pangal, "Dough-handling and cookie-making properties of wheat flour-watermelon protein isolate blends," Food and Bioprocess Technology, vol. 5, no. 5, pp. 1612-1621, 2012.

[12] B. Škrbić and J. Cvejanov, "The enrichment of wheat cookies with high-oleic sunflower seed and hull-less barley flour: impact on nutritional composition, content of heavy elements and physical properties," Food Chemistry, vol. 124, no. 4, pp. 14161422, 2011.

[13] B. Pareyt, F. Talhaoui, G. Kerckhofs et al., "The role of sugar and fat in sugar-snap cookies: structural and textural properties," Journal of Food Engineering, vol. 90, no. 3, pp. 400-408, 2009.

[14] S. A. Abrams, I. J. Griffin, K. M. Hawthorne et al., "A combination of prebiotic short- and long-chain inulin-type fructans enhances calcium absorption and bone mineralization in young adolescents," American Journal of Clinical Nutrition, vol. 82, no. 2, pp. 471-476, 2005.

[15] S. Hempel, A. Jacob, and H. Rohm, "Influence of inulin modification and flour type on the sensory quality of prebiotic wafer crackers," European Food Research and Technology, vol. 224, no. 3, pp. 335-341, 2007.

[16] F. Nazzaro, F. Fratianni, R. Coppola, A. Sada, and P. Orlando, "Fermentative ability of alginate-prebiotic encapsulated Lactobacillus acidophilus and survival under simulated gastrointestinal conditions," Journal of Functional Foods, vol. 1, no. 3, pp. 319323, 2009.

[17] K. R. Niness, "Inulin and oligofructose: what are they?" The Journal of Nutrition, vol. 129, no. 7, pp. 1402-1406, 1999.

[18] M. Shoaiba, A. Shehzada, M. Omar et al., "Inulin: properties, health benefits and food applications," Carbohydrate Polymers, vol. 147, pp. 444-454, 2016.

[19] Y. Bankole, A. Tanimola, R. Odunukan, and D. Samuel, "Functional and Nutritional Characteristics of Cassava Flour (Lafun) fortified with soybeans," Journal of Educational and Social Research, vol. 3, no. 8, pp. 163-170, 2013. 
[20] AOAC, Official Methods of Analysis, Association of Official Analytical Chemists, Arlington, Va, USA, 16th edition, 1995.

[21] CAA, Código Alimentario Argentino, Administración Nacional de Alimentos, Medicamentos y Tecnología Médica, Capítulo IX (Alimentos farináceos-cereales, harinas y derivados), 2014.

[22] S. Walker, K. Seetharaman, and A. Goldstein, "Characterizing physicochemical changes of cookies baked in a commercial oven," Food Research International, vol. 48, no. 1, pp. 249-256, 2012.

[23] A. Chauhan, D. C. Saxena, and S. Singh, "Total dietary fibre and antioxidant activity of gluten free cookies made from raw and germinated amaranth (Amaranthus spp.) flour," LWT-Food Science and Technology, vol. 63, no. 2, pp. 939-945, 2015.

[24] M. Moiraghi, P. D. Ribotta, M. H. Morcillo, O. J. Rubiolo, G. T. Perez, and A. E. León, "Influencia del contenido de almidón dañado sobre la calidad galletitera en harinas triticale," Agriscientia, vol. 2, pp. 3-8, 2003.

[25] American Association of Cereal Chemists (AACC), Approved Methods of the American Association of Cereal Chemists, American Association of Cereal Chemists (AACC), Eagan, Minn, USA, 9th edition, 2000.

[26] B. Pareyt, E. Wilderjans, H. Goesaert, K. Brijs, and J. A. Delcour, "The role of gluten in a sugar-snap cookie system: a model approach based on gluten-starch blends," Journal of Cereal Science, vol. 48, no. 3, pp. 863-869, 2008.

[27] D. R. Palatnik, M. V. Ostermann-Porcel, U. González, N. Zaritzky, and M. E. Campderrós, "Recovery of caprine whey protein and its application in a food protein formulation," LWT-Food Science and Technology, vol. 63, pp. 331-338, 2015.

[28] K. Zhu, P. J. Kanu, I. P. Claver, K. Zhu, H. Qian, and H. Zhou, "A method for evaluating Hunter whiteness of mixed powders," Advanced Powder Technology, vol. 20, no. 2, pp. 123-126, 2009.

[29] L. T. Rodriguez-Furlán, A. Pérez-Padilla, and M. E. Campderrós, "Improvement of gluten-free bread properties by the incorporation of bovine plasma proteins and different saccharides into the matrix," Food Chemistry, vol. 170, pp. 257-264, 2015.

[30] B. G. Muller and G. Tobin, "Evaluación de los nutrientes," in Nutrición y Ciencia de los Alimentos, p. 146, Editorial Acribia S.A., Zaragoza, Spain, 1993.

[31] M. Meilgaard, G. Civille, and B. Carr, Sensory Evaluation Techniques, CRC Press, New Jersey, NJ, USA, 4th edition, 2006.

[32] C.-Y. Ma, W.-S. Liu, K. C. Kwok, and F. Kwok, "Isolation and characterization of proteins from soymilk residue (okara)," Food Research International, vol. 29, no. 8, pp. 799-805, 1996.

[33] K. H. Vishwanathan, V. Singh, and R. Subramanian, "Influence of particle size on protein extractability from soybean and okara," Journal of Food Engineering, vol. 102, no. 3, pp. 240-246, 2011.

[34] K. H. McWatters, "Cookie baking properties of defatted peanut, soybean, and field pea flours," Cereal Chemistry, vol. 55, pp. 853863, 1978.

[35] B. Singh, M. Bajaj, A. Kaur, S. Sharma, and J. S. Sidhu, "Studies on the development of high-protein biscuits from composite flours," Plant Foods for Human Nutrition, vol. 43, no. 2, pp. 181189, 1993.

[36] F. Zucco, Y. Borsuk, and S. D. Arntfield, "Physical and nutritional evaluation of wheat cookies supplemented with pulse flours of different particle sizes," LWT-Food Science and Technology, vol. 44, no. 10, pp. 2070-2076, 2011.
[37] J. C. Cheftel, J. L. Cuq, and D. Lorient, Proteínas Alimentarias: Bioquímica, Propiedades Funcionales, Valor Nutricional, Modificaciones Químicas, Acribia, 1989.

[38] S. Chevallier, P. Colonna, G. Della Valle, and D. Lourdin, "Contribution of major ingredients during baking of biscuit dough systems," Journal of Cereal Science, vol. 31, no. 3, pp. 241-252, 2000.

[39] A. N. Rinaldoni, M. E. Campderrós, and A. Pérez-Padilla, "Physico-chemical and sensory properties of yogurt from ultrafiltreted soy milk concentrate added with inulin," LWT_Food Science and Technology, vol. 45, no. 2, pp. 142-147, 2012.

[40] J. M. W. Wong, C. W. C. Kendall, R. Souza, E. Azadeh, A. Marchie, and E. Vidgen, "The effect on the blood lipid profile of soy foods combined with a prebiotic: a randomized controlled trial," Metabolism Clinical and Experimental, vol. 59, no. 9, pp. 1331-1340, 2010. 

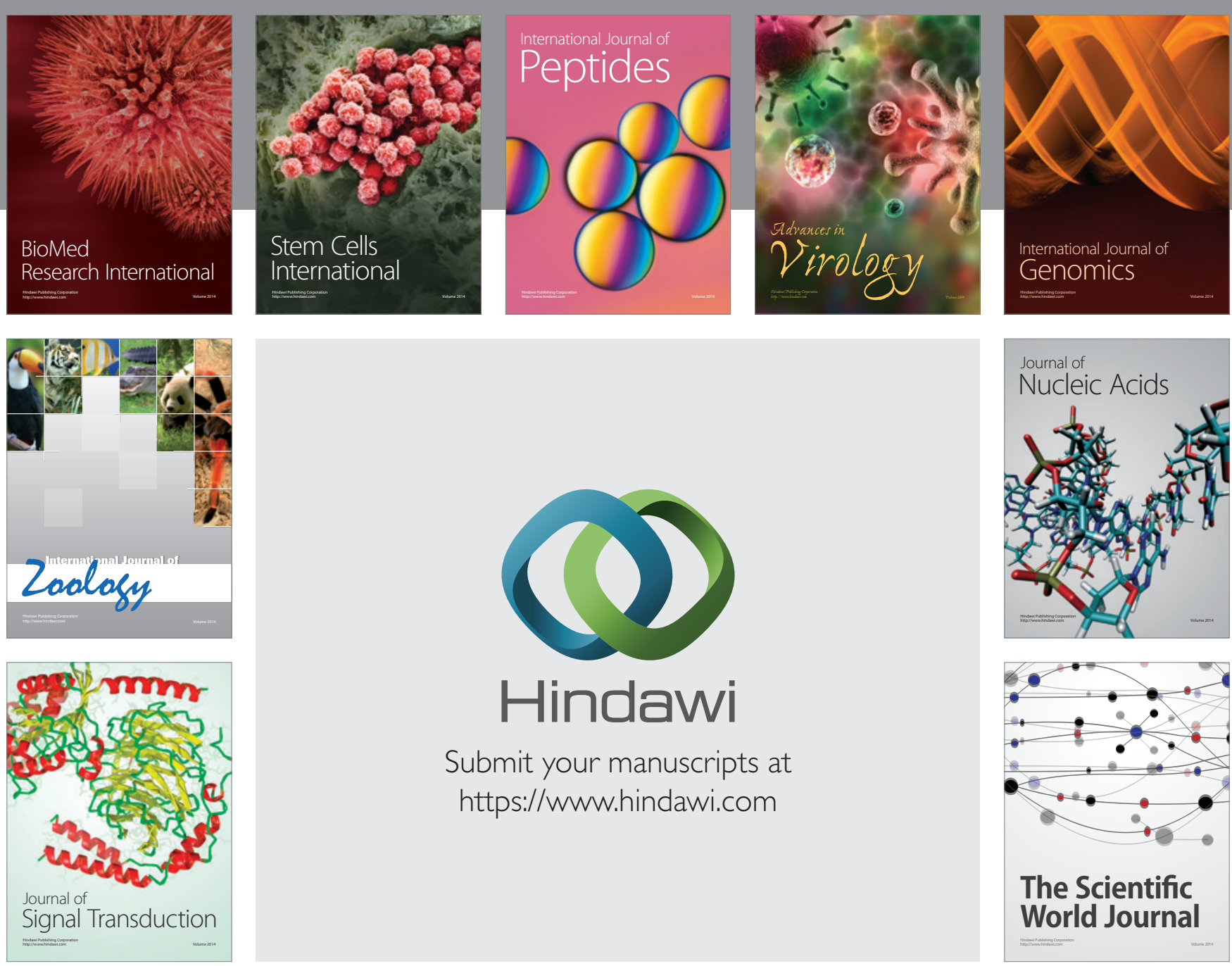

Submit your manuscripts at

https://www.hindawi.com
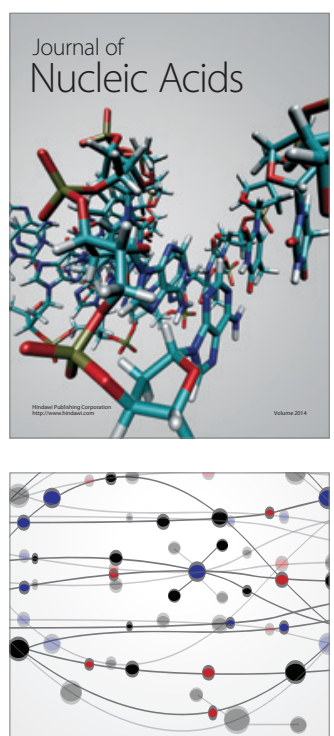

The Scientific World Journal
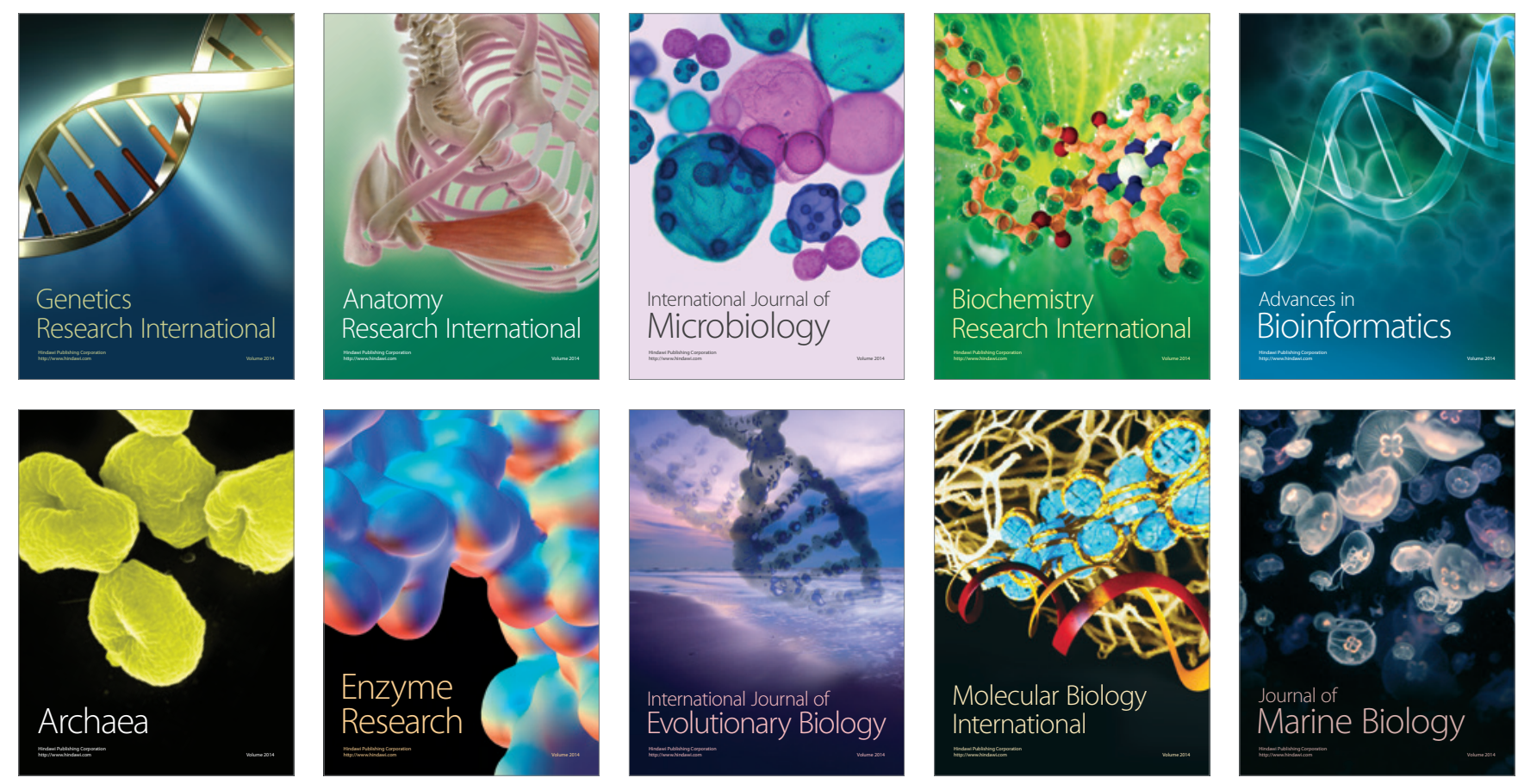